\title{
The Impact of Comprehensive Income Compared to Net Income on Share Prices of Egyptian Listed Companies
}

\author{
Eman M. Saad Eldeen \\ Faculty of Commerce - Beni Suef University, Egypt. \\ E-mail: emaneldeen2005@hotmail.com
}

\begin{abstract}
:
This study aims to examine whether comprehensive income (CI) is superior to net income (NI) in explaining changes in share price. The used sample comprises Forty four Egyptian listed companies during the period from 2017 to 2019. Limited studies have focused on the relevancy of reporting (CI) in developing countries and Egypt is no exception. The descriptive analysis reveals that the majority of sampled companies are profitable during the study period. Additionally, the mean of CI value (4.73), was relatively greater than that of NI (4.03), which suggests that CI is a major indicator of company performance. However, the findings indicate that NI is less variability compared to CI, since the latter includes some nonrecurring items. Furthermore, the regression analysis indicates that both comprehensive income and net income have a positive significant relationship with the share prices of Egyptian listed companies. But, CI has a higher power to explain variations in share price than NI. Anyhow, the author believes that disclosing both NI and CI is really beneficial, since they are complementary to each other.
\end{abstract}

Keywords: Comprehensive income, Value relevance, Share price, Net income, Egyptian listed companies

DOI: $10.7176 / \mathrm{RJFA} / 12-8-09$

Publication date: April $30^{\text {th }} 2021$

\section{Introduction}

Currently, many accounting bodies and professional organizations have shown a great interest towards the disclosure of other comprehensive income (CI) either in the income statement or in a single statement. The fact which can be assigned to the global widespread of IFRS adoption (Pascan, 2014). Also, the use of fair value to measure balance sheet items, resulting in unrealized gains and losses which need to be reported in other comprehensive income (OCI) (Yousefinejad et al.,2017; Bumane,2018).

In fact, the income statement provides users with useful information as to evaluate company's financial performance. Yet, the absence of comprehensive income disclosure makes it hard to offer a clear view about financial performance to investors. As reported by (Mulford \& Babinets, 2018), there are many other gains and losses which are not presented in the net income NI called other comprehensive income, although they obviously affect company's financial performance and net worth. Anyhow, professional organizations have encouraged entities to report comprehensive income because it introduces relevant and useful information to decision makers compared with traditional net income (e.g. Ozcan, 2015; Shi et al., 2017). In addition, measuring company performance relying on CI could produce better results, since all variations in net assets from non-owner sources can be seen over a period of time.

Recently, there is a huge debate regarding the usefulness, components and form of disclosing CI (Saymeh et al., 2019).In other words, accounting effects of adopting and presenting CI need more investigation, especially in Egypt as one of the emerging markets. It was found that studies concerning the effect of CI on financial performance and share price are very rare in the emerging economies, and Egypt is no exception. The study tries to fill in the gap by testing the effect of disclosing CI versus NI on share prices of Egyptian listed companies. The lack of empirical studies regarding this issue is the main reason that motivated the author to conduct this study. Egyptian listed companies have started to disclose a single CI statement from 2016 to comply with ministerial decree no. 110 in 2015.

The main objective of this study is to investigate the effect of reporting the comprehensive income compared to net income on the share prices of Egyptian listed companies during the period from 2017 to 2019. In addition, a comparative analysis of recent accounting standards related to CI components and disclosure will be also reviewed. It is aimed that the study findings could help regulatory agencies in Egypt to improve the Egyptian Accounting Standards (EAS) for more transparency and disclosure. 
The remainder of this paper is organized as follows: Section 2 highlights the definition, components of CI and the related accounting standards. Section 3 reviews the related literature and show hypothesis development. Section 4 encompasses research methodology including data and sample selection. Section 5 discusses the results of the study. Section 5 introduces the conclusion of the study.

\section{An Overview of Comprehensive Income}

In fact, introducing fair value measurement through (IFRS 13) valid from 2013, titled Fair Value Measurement, and revising IAS No. 1 by the IASB in 2007, have confirmed the disclosure of CI ( Rahman \& Wu, 2020). Also, measuring assets and liabilities using fair value resulted in unrealized gains and losses which should be shown in OCI.

Comprehensive income can be defined as the change in the net assets during the period, except those resulting from direct transactions with shareholders, which incorporates recognized assets and liabilities measured by using relevant measurement bases (Nishikawa et al., 2016). Alternatively, Comprehensive income is the sum of net income and other comprehensive items (Shi et al., 2017). Other comprehensive income contains items like changes in revaluation surplus, foreign currency translation adjustments, actuarial gains and losses from pension plans, gains and losses revaluation of available for sale securities and gains and losses on hedging instruments.

Initially, in 1997, the FASB issued SFAS No. 130 titled: Reporting Comprehensive Income, to incorporate the components and disclosure of CI in the financial statements (Oscan, 2015). In 2007, the IASB amended IAS No. 1 titled: Presentation of Financial Statements, and confirmed that companies should issue a statement of CI starting from 2009. The statement should show NI and specific items that generate other sources of income. As stated by (Bumane, 2018), OCI are those items- including reclassification adjustments - which are not recognized in profit and loss statement as allowed by other IFRS.

In Egypt, a new accounting standards version was issued in 2015 and revised in 2019 as to harmonize the EAS with the IFRS . It includes standard No.1, titled: Presentation of Financial Statements, which has required Egyptian listed companies to issue a standalone statement of comprehensive items starting from the financial year 2016.The EAS defined CI as the change in owners' equity during the period resulting from transactions and other events apart from changes resulting from direct transactions with owners. Total comprehensive income (TCI) includes all profit or loss items plus other CI. The standard has allowed only one alternative that is two separate statements to present CI.

Table 1 summarizes the main dissimilarities exist between accounting standards regarding other comprehensive income components and reporting. Comprehensive income is the sum of net income and other comprehensive items.

Table 1. Dissimilarities of OCI under Accounting Standards

\begin{tabular}{|c|c|c|}
\hline SFAS (130) (1997) & IAS No. 1 (2007 R) & EAS No. 1 (2015 R) \\
\hline \multicolumn{3}{|c|}{ Main Components } \\
\hline $\begin{array}{l}\text { - Adjustments for minimum } \\
\text { pension liability } \\
\text { - Foreign currency translation } \\
\text { adjustments } \\
\text { - Unrealized gain and losses on } \\
\text { investments in securities }\end{array}$ & $\begin{array}{l}\text { - Re-measurement of defined } \\
\text { plans. } \\
\text { - Gains and losses from investment } \\
\text { in equity instruments designated } \\
\text { at fair value } \\
\text { - Changes in revaluation surplus } \\
\text { - The effective part of gains and } \\
\text { losses on hedging instruments in } \\
\text { a cash flow hedge }\end{array}$ & $\begin{array}{l}\text { - Actuarial gains and losses from } \\
\text { defined employees' benefits plan } \\
\text { (EAS 38) } \\
\text { - Foreign currency translation } \\
\text { gains and losses (EAS 13) } \\
\text { - Gains and losses from revaluation } \\
\text { of available-for-sale financial } \\
\text { assets (EAS 47) } \\
\text { - The effective portion of gains and } \\
\text { losses on hedging tools used to } \\
\text { cover the cash flow (EAS 47) }\end{array}$ \\
\hline \multicolumn{3}{|c|}{ Reporting } \\
\hline $\begin{array}{l}\text { The standard allows three } \\
\text { alternatives: (Kim, 2016) } \\
\text { - One statement of CI which }\end{array}$ & $\begin{array}{l}\text { The standard permits } \\
\text { alternatives as follows: } \\
\text { (Ngmenipuo \& Issah, 2015) }\end{array}$ & $\begin{array}{l}\text { The standard allows only one } \\
\text { alternative which is two separate } \\
\text { statements: }\end{array}$ \\
\hline
\end{tabular}


includes components of NI and other comprehensive items ending with TCI

- Two separate statements: the first shows the components of NI, whereas the second starts with NI and incorporating OCI

- To disclose OCI in the statement of changes in Equity

\begin{tabular}{|c|c|}
\hline $\begin{array}{l}n \\
\text { nt } \\
n\end{array}$ & $\begin{array}{l}\text { - The income statement } \\
\text { encompasses components of } \\
\text { profit or loss } \\
\text { - CI statement starting with net } \\
\text { profit or loss and all other } \\
\text { comprehensive items ending with } \\
\text { TCI. } \\
\text { TCI is also shown as distributed } \\
\text { between minority shareholders and } \\
\text { parent company owners. }\end{array}$ \\
\hline & \\
\hline $\begin{array}{l}\text { Two alternatives are allowed } \\
\text { (Gazzola \& Amelio, 2014b) } \\
\text { - Other comprehensive income } \\
\text { components net of tax } \\
\text { - OCI components before tax } \\
\text { effect, with disclosing a single } \\
\text { amount of income tax expense } \\
\text { related to OCI items } \\
\text { Under both options, the tax amount } \\
\text { on every component is disclosed in } \\
\text { the notes. }\end{array}$ & $\begin{array}{l}\text { One alternative is permitted, OCI } \\
\text { should be presented before tax } \\
\text { effects and only single income tax } \\
\text { amount for those items is presented. } \\
\text { Tax amount for every other } \\
\text { comprehensive item is latter } \\
\text { displayed in the notes to the } \\
\text { statement }\end{array}$ \\
\hline
\end{tabular}
on every component is disclosed in the notes.

Source: compiled by the author

However, in 2011, the FASB has revised the disclosure of CI to be shown in either a single statement of CI or in two separate statements. The first is to show NI components, whereas the second starts with NI in addition to OCI items ending up with TCI and the third option was disregarded (FASB, ASU 2011-05, Topic 220).

\section{Literature Review and Hypothesis Development}

There is a huge body of studies concentrates in both value relevance of CI and its effect on financial performance. Comprehensive income can introduce more valuable information to investors about the overall financial stability of the organization ( Marchini \& D'este,2015). It may also help financial analysts to receive a more realistic measure of the fair value of a company's investments which ,in turn, improve their predictions (Saymeh et al.,2019 ). Previous studies about CI will be discussed through two main streams: the first concerning the impact of adopting CI on financial performance ; the second relating to the effect of disclosing CI on share price.

Some accounting literature has argued that CI disclosure could increase quality and transparency of financial reporting and hence, increase the ability of investors to evaluate company's financial performance. Goncharov \& Hodgson (2011) documented that absence of disclosing CI makes it hard to offer investors a clear idea about financial performance. Marchini \& D'este (2015) examined the impact of reporting unrealized gains and losses on financial ratios of Italian listed companies. The results indicated that disclosing comprehensive income has meaningfully affected companies performance. In addition, Firescu (2015) concluded that both net income and comprehensive income are beneficial in measuring company performance. The study of (Gazzola \& Amelio , 2014b) compared between comprehensive income and net income for better evaluation of companies performance. They relied on data published by companies listed on Czech Republic Stock Exchange. The results showed that comprehensive income yields more informative content to investors and provides more information about financial performance than net income. Similarly, Gazzola \& Amelio (2014a) examined the difference between calculating Return on Equity (ROE) using CI and net income for performance evaluation. They found that ROE using CI is superior to net income and is a good indicator of financial performance . Also, Saymeh et al. (2019) examined the impact of other comprehensive income on financial performance of Jordanian Commercial Banks. Their results revealed a significant effect of OCI on financial performance of sampled banks. Park (2018) reported that OCI has an additional relevant information, especially unrealized earnings, on decision making process. Further, Sajnog \& Sosnowski (2018) Pointed out that companies which report OCI are less likely to engage in aggressive accounting due to the negative relation among OCI and 
earning management.

On the contrary, In Jordan, (Bataineh \& Rababah, 2016) conducted a study to compare the ability of both CI and NI to forecast future performance of Jordanian listed companies. Their results revealed that net income is better in predicting future income than comprehensive income. But, total comprehensive income provides users with more informative contents. Correspondingly, Ozcan (2015) found that net income is better than CI to predict future operating income .Yet, CI is more useful to forecast return on equity and return on assets. Pascan, (2014) found that there is no significant difference between comprehensive income and net income in measuring financial performance of Romanian listed companies. He added that CI has no additional value relevance over net income. Moreover, the study of (Ngmenipuo and Issah, 2015) has used EPS to measure financial performance of Ghanaian listed companies. The results showed that there is no significant difference between EPS using comprehensive income and net income. They added that reporting CI does not provide any extra information about financial performance. Similar result was shown in Iran by (Dastgir \& Velashani, 2008), who reached that $\mathrm{CI}$ is not better that $\mathrm{NI}$ to evaluate performance in terms of stock returns.

On the other side, a number of studies have found that CI disclosure can positively affect share price. Yosefinejad et al., (2017) examine value relevancy of disclosing CI in Malaysian listed companies during 2011 to 2013. Their results reveal that OCI is value relevant and contributes to produce more informative financial reporting. Likewise, Khan et al., (2018) documented a significant association between TCI and share price compared with NI. Alike, the study of (Xu \& Qi, 2017) concluded that the value revelance of CI has improved after adopting a single performance statement during the study period. Anyhow, presenting OCI does not provide the same effect during the same period. Bumane (2018) found that the core of items of CI statement are really important to measure company performance. Moreover, Osemy (2020) added that the existence of audit committee improve both NI and CI.

Adversely, the study of (Jahmani et al., 2017) reported that comprehensive income and OCI are not value relevant. But, some CI components (e.g. derivatives, hedging and gains and losses on available-for-sale securities) have some value. Similar result was shown by Banks et al., (2018) who found that comprehensive income is less value-relevant compared with net income even after changing its reporting location. Elbayoumi \& Awadallah (2012) concluded that reporting OCI has not add value to predict cash flows, NI and stock returns. Furthermore, Schaberl \& Victoravich (2015) also emphasized a decline in the value relevance of OCI when companies locate it in statement of performance instead of statement of equity. Similarly, the study of (Harasheh et al., 2020) pointed out a weak negative relation among OCI and equity price. The results revealed that volatility of OCI increases equity risk. Other study reported that presentation of OCI has no clear effect on firm value of Indonesian listed companies (Kalbuana et al., 2020). Additionally, Usman et al., (2016) discussed value relevancy of CI compared with NI for Nigerian listed companies. They concluded that NI has a more value relevancy compared to $\mathrm{CI}$.

In short, prior studies on both performance evaluation and value relevancy of CI have introduced mixed evidences. They also found that fair value measurement has a realizable impact on relevancy of OCI value. I can differentiate this study from previous studies in many sides. First, most studies in CI have concentrated on developed countries, with efficient capital markets. Consequently, there is a need to better understand the impact of disclosing CI in emerging markets, and Egypt is no exception. Second, there is no much empirical evidence to enhance or against the influence of presenting OCI upon share prices. Thus, the study aims to decrease research gap in Egypt, regarding the preference of reporting CI over NI as a performance indicator.

To reach study objective, the author has relied on related prior studies as well as theoretical background to develop the following hypothesis:

Hypothesis 1: There is a strong significant association between comprehensive income and share prices of Egyptian listed companies compared to net income.

\section{Research Method}

\subsection{Data and Sample}

The data related to the empirical study was collected from published financial reports of the sampled companies, their official websites, and the official website of the Egyptian Stock Exchange (ESE) (www.egx.com.eg) and Mubasher website (www.mubasher.inf.com).

The initial sample is relied on the most active 50 companies listed on the (ESE) during the period from 2017 to 2019. This is because the mandatory application of reporting single CI statement has started since the fiscal year 
2016. Following prior researches, companies with missing date; measuring performance in dollar amount; financial firms and those which don't show any CI components are eliminated.

The final sample comprises of 44 listed companies for a period of three years from 2017 to 2019 with 132 firmyear observations.

\subsection{Empirical Models and Variables Description:}

In fact, the share price is a major performance indicator of companies' performance. Fluctuation of the prices, normally, is connected with information available to investors, which helps them to make investment decisions (Mubarak, 2018).

To examine the explanatory power of CI to net income on stock market prices, the study uses two models as discussed in prior studies (e.g. Dastgir \& Velashani, 2008; Xu \& Qi, 2017 ; Khan et al., 2017). The share price represents the dependent variable, whereas the independent variables include book value of common equity, net income and comprehensive income.

$$
\begin{aligned}
& \mathrm{Pit}=\mathrm{B} 0+\mathrm{B} 1 \mathrm{BVE}+\mathrm{B} 2 \mathrm{NI}+\varepsilon \\
& \mathrm{Pit}=\mathrm{B} 0+\mathrm{B} 1 \mathrm{BVE}+\mathrm{B} 2 \mathrm{COMP}+\varepsilon
\end{aligned}
$$

Where:

Pit $=$ closing share price four months after the fiscal year end $-(i, t)$ firm year

$\mathrm{BVE}=$ the book value of equity per share at the end of fiscal year

$\mathrm{NI}=$ annual net income per common share for fiscal year

$\mathrm{COMP}=$ comprehensive income per common share $(\mathrm{NI}+\mathrm{OCI})$ for fiscal year

\section{Results}

\section{Descriptive statistics}

Table 2 below indicates the result of descriptive statistics test of the dependent variable and independent variables with mean, and standard deviation.

Table 2. Descriptive statistics

\begin{tabular}{|l|c|c|c|c|c|}
\hline \multicolumn{1}{|c|}{ Items } & N & Mean & Std. & C.V & Rank \\
\hline Y. Pit & 132 & 39.70 & 208.13 & 19.07 & 2 \\
\hline x1. COMP & 132 & 4.73 & 23.47 & 20.15 & 3 \\
\hline x2. NI & 132 & 4.03 & 22.03 & 18.29 & 1 \\
\hline x3. BVE & 132 & 16.34 & 49.05 & 33.31 & 4 \\
\hline
\end{tabular}

Table 2 provides a description of the sample. It is clear that most of the sampled companies are profitable over the period 2017 to 2019. The variable (NI), has a mean (4.03), and a standard deviation (22.03). Also, the mean shows that the variable (COMP) per share was positive and higher than (NI), with a mean (4.73), and a standard deviation (23.47). The result suggests that $\mathrm{CI}$ is a core indicator of company performance. The results indicated that $(\mathrm{NI})$ is less variability, followed by the share price (Pit), and (COMP), with coefficient of variation, $(18.29 \%),(19.07 \%),(20.15 \%)$ respectively. This is because CI includes some nonrecurring items.

Table 3 below shows the correlation coefficient of Pearson correlation which is used to measure the direction and strength of the relationship between independent and dependent variables. The results show that there is a significant strong positive relationship between the independent variable (COMP) and the dependent variable, share price (Pit) with a correlation coefficient (0.965) at a level of significant less than (0.001). Additionally, there is a significant positive relation between the independent variable (NI) and share price (Pit) with a correlation coefficient (0.921) at a level of significant less than (0.001). However, the correlation of CI per share exceeded the NI per share during the study period. 
Table (3) Pearson correlation

\begin{tabular}{|c|c|c|c|c|}
\hline Variables & Pit & COMP & NI & BVE \\
\hline x1. COMP & $0.965^{* *}$ & - & - & - \\
\hline x2. NI & $0.921^{* *}$ & $0.877^{* *}$ & - & - \\
\hline $\mathrm{x} 3 . \mathrm{BVE}$ & $0.937^{* *}$ & $0.947^{* *}$ & $0.941^{* *}$ & - \\
\hline
\end{tabular}

** Significant level 0.001

Table 4 below reveals results of using multiple regression analysis to study the relationship between dependent variable and the independent variables.

Table 4. Relationship between study variables

\begin{tabular}{|c|c|c|c|c|c|c|c|c|}
\hline \multirow{2}{*}{ Model } & \multirow{2}{*}{$\begin{array}{c}\text { Independent } \\
\text { variables }\end{array}$} & \multirow{2}{*}{$\beta$} & \multicolumn{2}{|c|}{ t. test } & \multirow{2}{*}{$\begin{array}{c}\text { Standardized } \\
\text { B }\end{array}$} & \multicolumn{2}{|c|}{ F. test } & \multirow{2}{*}{$\mathrm{R}^{2}$} \\
\hline & & & Value & Sig. & & Value & Sig. & \\
\hline \multirow{3}{*}{1} & Constant & -7.26 & -1.423 & 0.157 & - & \multirow{3}{*}{959.21} & \multirow{3}{*}{$0.001 * *$} & \multirow{3}{*}{$93.7 \%$} \\
\hline & x1 COMP & 6.725 & 10.976 & $0.001 * *$ & 0.219 & & & \\
\hline & x3 BVE & 0.928 & 3.164 & $0.002 * *$ & 0.758 & & & \\
\hline \multirow{3}{*}{2} & Constant & -15.98 & -2.367 & $0.019 *$ & - & \multirow{3}{*}{530.16} & \multirow{3}{*}{$0.001 * *$} & \multirow{3}{*}{$89.2 \%$} \\
\hline & X 2 NI & 3.234 & 3.990 & $0.001 * *$ & 0.342 & & & \\
\hline & X 3 BVE & 2.610 & 7.168 & $0.001 * *$ & 0.615 & & & \\
\hline
\end{tabular}

** Significant level 0.001

As appeared in table (4), model 1, the coefficient of determination (R2) shows that the independent variables (COMP) and (BVE) explain (93.7\%) of the total variation in the dependent variable, share price (Pit) and the rest of the ratio, is due to random error in the equation, or perhaps the lack of inclusion of others independent variables, that were supposed to be included within the form.

To test the quality of the model as a whole, (F-test), has a value (959.21), with significant level less than (0.001), indicating goodness of fit of the model.

In addition, the independent variables (COMP) and (BVE) have a significant effect on the dependent variable share price (Pit) as the values of " $\mathrm{t}$ " are (10.976), (3.164) respectively, with a significant level less than (0.001). The regression model indicates a positive significant relationship among comprehensive income and share price. From the above table, the relationship can be presented by the following regression equation:

$$
\text { Pit }=-7.26+6.725 \mathrm{COMP}+0.928 \mathrm{BVE}
$$

Moreover, in model 2 , the coefficient of determination (R2) indicates that the independent variables (NI) net income per common share and (BVE) explain (89.2\%) the total variation in the dependent variable share price (Pit) and the of rest of the ratio, could be assigned to random error in the equation, or the lack of inclusion of others independent variables. The F-test has a value of (530.16), with a significant level less than (0.001), which statistically enhances the significance of the model.

The independent variables (NI) and (BVE) have a significant impact on the dependent variable (Pit) as the values of " $t$ " are (3.990), (7.168) respectively, with significant level less than (0.001). The regression model reveals a positive significant relation between the net income and share price. From the above table, The relation can be shown by the following equation:

$$
\text { Pit }=-15.98+3.234 \mathrm{NI}+2.610 \mathrm{BVE}
$$

In short, the regression models highlights that both comprehensive income and net income have a positive significant relationship with the share prices of Egyptian listed companies. But, CI has a higher power to explain variations in share price than NI. As a result, the study hypothesis is accepted. Similar results were reported by 
some previous studies ( e.g. Yousefinejad et al.,2017; Xu \& Qi, 2017; Khan et al., 2018). This result enhances the discussion that investors are more interested to know CI value, especially, after the adoption of EAS (1) effective 2016. Furthermore, The EAS (1) has permitted only two separate statements to report CI, which highlights its importance and decreases confusion among users. However, The findings are not supported by another studies (e.g. Elbayoumi \& Awadallah ,2012; Pascan, 2014; Banks et al., 2018; Harasheh et al., 2020).

\section{Conclusion}

The study is basically aimed to investigate the superiority of CI over NI to explain changes in share prices of Egyptian listed companies. In fact, CI has received lots of attention from professional organizations during the last two decades. It could overcome the current shortcomings of the income statement and enable investors to better evaluate company performance. Recently, Egyptian companies has started to present a single CI statement to comply with ministerial decree No. 110 in 2015 (an amendment of EAS 1) effective from 2016. To fulfill study objective, an empirical study has been implemented for a sample of (44) Egyptian listed companies over three- year period from 2017 to 2019.

To test the study hypothesis, two regression models were developed, in which the share price represents the dependent variable, whereas book value of common equity, net income and comprehensive income constitute the independent variables. Descriptive analysis shows that the majority of sampled companies are profitable during the study period. Also, the mean of CI value (4.73), was relatively greater than that of NI (4.03), which suggests that $\mathrm{CI}$ is a major indicator of company performance. However, The findings indicated a low variation in NI compared to CI, since the latter includes some nonrecurring items.

Collectively, the regression analyses show that both comprehensive income and net income have a positive significant effect on the share prices of sampled companies. Yet, the results indicate that CI is more strongly associated with share prices of Egyptian listed companies. Moreover, the book value of equity in the two models are significant which improves the explanatory power of them. This finding documents that comprehensive income is more value relevant than net income. Therefore, the study hypothesis is accepted. In fact, the author believes that disclosing both NI and CI is really beneficial, since they are complementary to each other. It is aimed that the study findings could help regulatory agencies in Egypt to improve the (EAS 1) and to motivate companies to adopt the standard for more transparency and disclosure.

The Study has some limitations which restrict generalization of the findings. First, the sample are limited to 44 Egyptian listed companies for a period of three years. If the sample enlarged to the case 100 for a longer time period as to support statistical tests. Second, another study may investigate the level of disclosing CI components by privately held companies. Third, the ability of CI to predict future earnings and persistency could be also examined. Fourth, similar studies are required to test CI issue in another developing countries. Moreover, a research could be conducted before and after the adoption of EAS 1, to document its effect on improving financial reporting quality in Egypt.

\section{References}

Banks, L., Hodgson , A. \& Russell, M. (2018). The location of comprehensive income reporting - does it pass the financial analyst revision test? Accounting Research Journal, 31( 4), 531-550.

Bataineh, A. \& Rababah, A. (2016). Comprehensive income and net income, which is more powerful in predicting future income. International Journal of Academic Research in Accounting, Finance and Management Sciences, 6(2), 114-120.

Biddle G. \& Choi J. (2006), Is comprehensive income useful? Journal of Contemporary Accounting and Economics, 2,(1), 1-32.

Būmane, I. ( 2018). The methodology of the statement of comprehensive income and its impact on profitability: the case of Latvia, Entrepreneurship and Sustainability Issues 6(1), 77-86. http://doi.org/10.9770/jesi.2018.6.1(6)

Chambers, D., Linsmeier, T., Shakespeare, C., \& Sougiannis, T. (2007). An evaluation of SFAS No. 130 comprehensive income disclosures. Review of Accounting Studies, 12(4), 557-593.

Dastgir, M. \& Velashani, A. (2008). Comprehensive income and net income as measures of firm performance: some evidence for scale effect. European Journal of Economics, Finance and Administrative Sciences, 12 , 123-133

Elbayoumi, A. \& Awadallah, E. (2012). The incremental usefulness of other comprehensive income items to the 
Egyptian investor. International Journal of Economics and Accounting,3( 3/4 ), 295-321.

Financial Accounting Standards Board.(2011). Accounting Standard Update No. 2011-05: Comprehensive income ( topic 220 ): Presentation of Comprehensive Income (FASB)

Firescu, V. (2015). Comprehensive income, a new dimension in performance measurement and reporting, Procedia Economics and Finance, 20,218 - 223

Gazzola, P. \& Amelio, S. (2014a). The impact of comprehensive income on the financial ratios in a period of crises. Procedia Economics and Finance, 12, 174-183

Gazzola, P. \& Amelio, S. (2014b). Is total comprehensive income or net income better for the evaluation of companies' financial performance? Central European Review of Economic Issues, 17, 40-51.

Goncharov, I. \& Hodgson, A. (2011). Measuring and reporting income in Europe, Journal of International Accounting Research ', 10(1). 27-59.

Graham, R. \& Lin, K. (2018). The influence of other comprehensive income on discretionary expenditures, Journal of Business Finance \& Accounting, 45,72-91.

Harasheh, M., Doni, F., Franceschelli, M. \& Amaduzzi ,A. (2020). The value relevance of Other Comprehensive Income: Extensive evidence from Europe. International Journal of Finance and Economics, 1-17. https://doi.org/10.1002/ijfe.1990

He, H. and Lin, Z. 2015. Analyst following information environment and value relevance of comprehensive income: Evidence from China, Asia-Pacific Journal of financial Studies, 44, 688- 720.

Jahmani, Y., Choi, H., Park, Y. and Wu, G. (2017). The Value Relevance of Other Comprehensive Income and Its Components, Accounting and Taxation, 9(1),1-11.

Kalbuana, N., Yohana, Agustina \& Aryadi, R, (2020). Effect of audit quality, tax avoidance, leverage. and presentation of other comprehensive income on firm's value in Jakarta Islamic index company, Journal of Islamic Economics Perspectives, 2. (1), 1-11

Khan, S., Bradbury, M. \& Courtenay, S. (2018). Value Relevance of Comprehensive Income. Australian Accounting Review, 28(2), 279-287.

Kim. J. (2016). Presentation formats of other comprehensive income after accounting standards update 2011-05, Research in Accounting Regulation, 28 118-122

Marchini, P. \& D'este, C. (2015). Comprehensive income and financial performance ratios: which potential effects on ROE and on firm's performance evaluation?. Procedia Economics and Finance, 32, 17241739 .

Mubarak, A. (2018). Impact of industry, operations in foreign currency, type of ownership on comprehensive income - the case of Egyptian companies. Accounting Thought, 22 (5),3-22.

Mulford, C. \& Babinets, A. (2018). Corporate reporting of other comprehensive income. International Journal of Accounting and Financial Reporting, 8(2), 212-235.

Ngmenipuo, I. \& Issah, O. (2015). The impact of comprehensive income reporting on financial performance of Ghanian firms with public accountability. International Journal of Economics, Commerce and Management, 3(3), 1-12.

Nishikawa, I., Kamiya, T., \& Kawanishi, Y. (2016). The definitions of net income and comprehensive income and their implications for measurement. Accounting Horizons. 4(30), 511-516.

Osemy, A. (2020). The impact of corporate governance on the financial reporting quality in Saudi banks, Global Journal of Economics and Business, 8 (1), 166-179.

Ozcan, A. (2015). How well does comprehensive income measure future firm performance compared to net income? Evidence from Turkish listed firms. Business and Management Studies: An International Journal, 3(3), 309-326.

Park, H. (2018). Market reaction to other comprehensive income, Sustainability, 10 (6), 1-14.

Pascan, I. (2014). Does comprehensive income tell us more about an entity's performance compared to net income? Emerging Markets Queries in Finance and Business, 15, 1077-1082.

Rahman , M. \& Wu, T. (2020). Volatility of other comprehensive income and audit fees: evidence from China, International Journal of Disclosure and Governance, 1-15, https://hdl.handle.net/20.500.12540/277 
Sajnóg, A. (2019). Executive Compensation and Comprehensive Income: Evidence from Polish Listed Companies, Oeconomia Copernicana, 10 (3) , 493-509.

Sajnóg, A. \& Sosnowski, T. 2018. The effect of other comprehensive income reporting on accruals-based earnings management activities, Oeconomia Copernicana, 3, 128-135.

Saymeh, A., ALkhazaleh, A. \& Musallam, E. (2019). The Impact of Other Comprehensive Income Items on Financial Performance: Case of Jordanian Commercial Banks. The Journal of Social Sciences Research, 5(4), 881-893.

Schaberl, P. \& Victoravich, L. (2015). Reporting location and the value relevance of information: the case of other comprehensive income, Advances in Accounting, Incorporating Advances in International Accounting, 31, 239-246.

Shi, L., Wang, P. \& Zhou, N. (2017). Enhanced disclosure of other comprehensive income and increased usefulness of net income: The implications of Accounting Standards Update 2011-05, Research in Accounting Regulation, 29, 139-144.

Usman, A., Amran, N. \& Shaari, H. (2016). The Value Relevance of Comprehensive Income in Nigerian: A Pilot Test, International Journal of Economics and Financial Issues, 6 (2),793-797

Wei, Z. \& Xue., J. (2015). Fair value accounting of financial assets and analyst forecast, China Journal of Accounting Studies, 3 (4), 294-319

$\mathrm{Xu}, \mathrm{W}$. and Qi, M. (2017). Presentation pattern and the value relevance of comprehensive income: evidence from China. International Journal of Economic and Finance, 9(6), 31-37.

Yousefinejad, M., Ahmad, A. \& Embong, Z. (2017). Value relevance of other comprehensive income and its available-for-sale financial instruments (AFS) and revaluation surplus of property, plant and equipment (REV) components. Asian Journal of Accounting and Governance, 8, 133-143.

Zhao, X., Zhao, K. \& Wei. W. (2018). Earnings Management using Other Comprehensive Income Items: A Multi-Case Study on Chinese Listed Companies, 2nd International Conference on Social Sciences, Arts and Humanities (SSAH 2018). 